\title{
Israel-Palestine Conflict: How Far the Solution is?
}

\author{
Dr Fahmida Aktar* \\ Associate Professor Department of Political Studies Shahjalal University of Science and Technology, Sylhet- \\ 3114 \\ *Corresponding Author: Dr Fahmida Aktar, Associate Professor Department of Political Studies \\ Shahjalal University of Science and Technology, Sylhet-3114
}

\begin{abstract}
Israel-Palestine Conflict is one of the modern phenomena. Most of the time Palestine-Israeli Conflict presented as a religious hatred. But the Conflict was rooted in the Politics of competing claims over land. The Conflict started after the U.N. Partition Plan in 1947. The majority of Palestine is Arab, but in U.N. Partition ninety percent of Arab is going deprived of their right. Before the second world war, Palestine was the place of Arab, Cristian, and Jews. The majority of people were from Islam religion. In the Balfour Declaration in 1917, England promised land for Jews people. According to this, in 1947, the U.N. divided Palestine into two parts, where Jews people got more than fifty-six percent, and forty-three percent remain to the Muslim majority. This decision made the Arab States angry, and later, the Conflict was created. The Conflict is alive for more than seven decades. This paper tries to understand the causes of Conflict and how it will be minimized or solved -for this, used to Conflict theory and the approaches of Conflict Resolution. This study is qualitative.
\end{abstract}

Keywords: Israel, Palestine, Conflict, Partition, Refugee, Settler, Resolution.

\section{INTRODUCTION}

Palestine's history has been marked by political conflict and violent territorial grabs due to its religious importance and strategic position between Africa and Asia.The situation regarding control of this area is complicated and changing. There is no international agreement on the boundary, and Israelis have occupied several territories claimed by Palestinians for years. Although more than 135 UN member nations recognize Palestine as an independent state, Israel and a few other countries, notably the United States, do not (Simon, 2010).

The name "Palestine" is derived from the Greek word "Philistia," which refers to the Palestinians who lived in the region in the 12th century B.C. Different peoples have ruled Palestine throughout history, including the Assyrians, Babylonians, Persians, Greeks, Romans, Arabs, Fatimids, Seljuk Turks, Crusaders, Egyptians, and Mamlukes (History. Com, 2021).

The Ottoman Empire controlled most of the area from approximately 1517 until 1917. The British gained control of Palestine when the First World War concluded in 1918. The League of Nations granted a British mandate for Palestine. This agreement, which entered into force in 1923, gave Britain administrative authority over the area and contained provisions for establishing a Jewish national state in Palestine (Ibid).

\section{RESEARCH METHODOLOGY}

The study used a qualitative approach. The research collected data via secondary sources such as journal articles, newspapers, books, and online resources. Content analysis was used to examine documents to determine their logical sequence.

\section{BACKGRound AND THE CAUSES OF THE CONFLiCT}

There are biblical promises made to Abraham and his descendants and that Israel was historically located here, supporting Jewish claims to the land that the Roman Empire had sacked. They view a Jewish state as the sole safe refuge from anti-Semitism in Europe. Palestine's claims to the ground are based on the fact that they have lived there for millennia and are the majority. 
During WWI, British High Commissioner MacMahon promised that if Arabs supported Britain, the British government would support Palestine, Transjordan, Syria, and Iraq's independence. (Cabuu.org, 2021). During the war, however, Britain made additional pledges that contradicted Hussein and McMahon's agreement. In 1917, British Foreign Minister Lord Arthur Balfour declared his government's support for a Jewish national home in Palestine (the Balfour Declaration). A third pledge was a secret agreement between Britain and France to break up the Ottoman Empire's Arab territories and share power.

The United Nations General Assembly passed Resolution 181 in 1947, which established two nations in Palestine, one Jewish and one Arab, with Jerusalem and Bethlehem designated as international zones. The Zionist leadership publicly supported the UN decision. Make a partitioning plan. The Arab states of Palestine have rejected the United Nations resolution Plan (Ibid).

The day after the United Nations adopted the Palestinian Declaration of Independence, fighting between Arab and Jewish inhabitants of Palestine became more intense. Armed forces from neighbouring Arab nations said that they would come to the Palestinians' aid. After the conflict between Israel and Arab nations, Palestine was divided into three parts. Approximately 77 percent of Palestine's territory is under Israeli control. Jordan took over the administration of the West Bank and the remainder of Palestine's territory. However, Egypt took control of the Gaza Strip, a tiny Mediterranean coastal region.

More than seven million Palestinian people have left for their lives, leaving behind their dwellings and belongings to become homeless. The world's most enormous refugee population is found in Palestine. The majority of Palestinian refugees in the area reside in 59 recognized camps. UN, UDHR, Fourth Geneva Convention, Hague Convention, International Covenant on Civil and Political Rights, etc., all support Palestine's claim to an opportunity to return home(Caabu, 2021).

Israel waged war in 1967 in reaction to Egyptian President Nasser's accusations. Israel had taken the West Bank from Jordan, the Gaza Strip and the Sinai Peninsula from Egypt, and the Golan Heights from Syria in only six days. Egypt has subsequently regained control of the Sinai Peninsula. But Israel still occupies the West Bank, Gaza, and Golan Heights. In the freshly captured West Bank and Gaza Strip, Israel has established an army administration.

After 20 years of Israeli occupation, the Palestinians in the West Bank and Gaza Strip fought against Israeli authority in 1987 (First Intifada). Millions of people, including kids, adolescents, and females, took part in the Intifada. Soldiers were beating up youngsters and, on one occasion, intentionally breaking the bones of juvenile detainees with rocks while shooting live fire and tear gas at stonethrowing protesters. Israeli troops murdered over 1000 people (History. Com, 2021).

The Oslo Peace Process was founded on Israel and the Palestinian Liberation Organization (PLO) mutual recognition. The Oslo Accords established a bargaining process not defining a final result on critical problems, including Israel's territorial concessions, the fate of Jewish settlements and residents, mineral rights, the refugee influx, and Jerusalem's future. As part of Oslo, the Palestinian Authority was formed, with self-governing powers in sovereign land at which the Israeli military is leaving. They controlled just a tiny part of the territory and had no full authority over any of them.

The last Oslo negotiations, known as the Camp David Summit, failed in 2000. The Palestinians were blamed for the peace process's collapse since they were accused of rejecting Israel's generous offer. The generous offer would have included the following:

1. For the Palestinian State, there is no geographical contingency.

2. It has little control over its vast boundaries.

3. It has just a limited amount of control over its water resources.

4. The Israeli occupation of occupied territory has not ended yet mandated under international human rights law.

5. A large part of the West Bank is under Israeli authoritarian rule.

6. Israeli troops can apply quickly throughout the State of Palestine.

7. There are still fortified Israeli enclaves and Jewish-only roads in the heart of the Palestinian State. 
All parties used more power than they did during the first Intifada. In 2002, Israel started building a barricade around the West Bank that spans the length of the territory. The wall, which is yet unfinished, has already affected millions of Palestinians. The barrier encircles Palestinian villages and cities, separating social fabric, isolating cultivators from their farmland, laborers from their employment, teachers, students from academic achievement, and the ill with hospital treatment. (Araj \& Brym, 2006). Israeli settlements in the West Bank dictated the barrier's path, often leaving extra territory available for expansion. The International Court of Justice found the wall to be unconstitutional. Despite this, Israel continues to construct it.

In the occupied Palestinian territories, democratic elections were held in 2006. Hamas, an Islamic group, was victorious. The West Bank is under Fatah rule, Gaza is under Hamas control, and The international community has ostracized Gaza.

Tensions between Israel and Gaza rose after Hamas won most seats in the Palestinian Legislative Council in the January 2006 Palestinian Legislative election. Israel closed the border with Gaza, preventing people and many products and commodities from freely moving. Over 70\% of Gaza's labor is unemployed or underpaid, while around $80 \%$ of the population lives in poverty.

The internal confrontation between Hamas and Fatah began in June 2007, when Hamas consolidated its power by staging an armed coup and taking control of Gaza. The Hamas government took complete control of the Gaza Strip after the 'War of Gaza 2007'.

Palestinian armed factions in Gaza and Israel have continued to fight since Hamas' control. These included 'Operation Summer Rains'-2006, the Gaza Beach Blast, in which Israel found 20 tunnels used for illicit weapons smuggling under the Gaza Strip's border with Egypt on 18 October 2006. Then, on 1 November 2006, Israel began Operation 'Autumn Clouds'. Israel proclaimed Gaza a 'hostile territory in September 2007 and blocked power, gasoline, and other supplies into Gaza, a move widely criticized as 'Collective Punishment'. The Gaza-Egypt border breach started on 23 January 2008. According to the United Nations, close to half of Gaza's 1.5 million residents crossed the border into Egypt in search of food and supplies.

On 29 February 2008, the Israeli military began operation 'Hot Winter,' also known as 'Warm Winter.' Israel pursued Hamas with Operation 'Cast Lead.' This battle is widely regarded as the most significant, most destructive, and the deadliest military campaign in Gaza since the 1967 Six-Day War. Again, a cross-border assault happened in 2011. The Israel Defense Forces (IDF) launched Operation 'Returning Echo' in the second week of March 2012. Operation the 'Pillar of Defense' took place in October 2012. In 2014, after 50 days of fighting, the Gaza War concluded with a ceasefire on 26 August 2014.

In 2018, the Border Protest War erupted, killing 168 Palestinians and injuring others at Gaza-Israel border. In 2019, another confrontation between Gaza and Israel erupted. On April 15, 2021, Israel's military-launched airstrikes on targets in Gaza in response to a rocket fired towards southern Israel. Hamas requested that Israel withdraw its troops from the Al-Aqsa mosque by 6 PM on May 10. Minutes provided that the deadline had gone. From Gaza, Hamas launched more than 150 missiles against Israel. Israel responded the following day with airstrikes in the Gaza Strip. Israel and Hamas have agreed to suspend hostilities as of May 20. A ceasefire agreement mediated by Egypt, Qatar, and the United Nations was implemented between Israel and Hamas at about 2.00 AM on May 21, 2021, ending 11 days of warfare.

\section{Peace Process of the Conflict}

For decades, the Israeli-Palestinian conflict has been fought on several fronts. Nobody knows what will happen next. A struggle ensued after the announcement of Palestine's partition, and the issue remains unresolved as of today (2021). Along with the troops, many civilians and children were killed, About 300 billion dollars loosed and more than 4,70,000 deaths still counted in this conflict. This war also harmed the ecosystem and damaged numerous historical sites. This feud reached a peak.

Meanwhile, Clinton negotiated a peace treaty with the United Nations, known as the Oslo Peace Accord. However, neither country took it into account. In 2000, the US President, Israeli Prime Minister, and Palestinian Prime Minister gathered in Camp David. Still, this meeting, too, ended without a resolution. Arabs proposed the recognization of Israel and Palestine in 2002, but this pact was also unsuccessful. 
Between 2010 and 2015, foreign organizations and the US proposed peace negotiations. However, the dispute does not seem to be over. In Paris in 2015, 70 countries struck a pre-emptive agreement on the Israel-Palestine issue. However, neither country was represented. In 2019, the United States took efforts to resolve the dispute, but Palestinians condemned it, saying that the US was speaking on Israel's behalf. The politics of the Middle East have altered dramatically in the years 2019-2020. Now that the dispute has escalated, there are many problems that will be difficult to resolve in a single day. UAE offered a truce in 2020, during the Pandemic period, via UN intervention. It's extremely encouraging that two nations have decided to declare a cease-fire in Gaza. After an 11-day bloody battle, these two nations negotiated a truce in May 2021.

\section{THEORITICAL FRAMEWORK}

Simply Conflict is a term that refers to a scenario in which two or more parties are vying for the same objective. It is a global phenomenon. Gillin and Gillin (1948) Conflict as an intentional effort to achieve goals via the defeat of others (Gillin \& Gillin,1948). Conflict is a technique or process people or organizations engage to accomplish their objectives ( Green \& Charles, 2012). It is not essential to presumptively believe that Conflict must always be destructive. Occasionally, it is a method of development.

The nature of conflict differs depending on culture, person, and state. However, all forms of conflict have a common framework. Johan Galtung, a renowned academic, sketched a common framework of conflict. He argued that every dispute consists of the following three fundamental components: 1 . Confrontational Situation 2. Attitudes Towards Conflict 3. Confrontational Behaviour.

\subsection{Confrontational Situation}

Confrontational situations are when two or more individuals or components get engaged to accomplish conflicting objectives. The objectives may not be the ultimate reward, peace, or victory; achieving these objectives may also entail other costs. For instance, Palestine and Israel are embroiled in a conflict for control of the territory of Palestine. Their goals are contradictory in this Conflict. If they gain something, they also lose something else. This component is prevalent in all forms of Conflict. Due to a lack of resources or other reasons, three types of situations may arise: a) Cooperation, b) Conflict, and c) Isolation.

\subsection{Attitudes Towards Conflict}

It is a term that refers to the attitudes of people or organizations that are engaged in conflict. According to legend, conflict starts with the human mind. Thus, conflict may also emerge from an individual's or group's attitude toward a particular object; ego, greed, aggressiveness, and belief all contribute to the development of the conflict in a scenario.

\subsection{Confrontational Behaviour.}

Where There Is Confusion While attitude and disagreement may seem to be hidden, action is always visible. It refers to the activities done by organizations or individuals in times of conflict. Thus, it encompasses the violence perpetrated by opposing groups to achieve their stated objective.

Galtung and Michell assert that a conflict may originate or arise from any of these three places. Conflicts may begin with an adversarial attitude toward the other party, resulting in a competitive environment and violent behavior. Conflict occurs when two parties have conflicting objectives and a slight possibility of achieving them.

\section{IMPORTANT CONCEPTUAL TERMS CONCERNING THIS CONFLICT}

In the analysis of the Israeli-Palestinian conflict, specific conceptual terms must be defined. These are as follows:

\section{$>$ Nakba}

The 1948 war uprooted 700,000 Palestinians, resulting in a refugee crisis that has yet to be resolved; Palestinians call this "mass expulsion." Catastrophe, the Arabic equivalent of the Nakba, and its aftermath remain one of the most contentious issues in current peace negotiations.

\section{Gaza}


Gaza is a highly-populated area of territory bordered nearly entirely by Israel and inhabited almost entirely by Palestinians. Israel had a military presence in the area until unilaterally withdrawing in 2005. An Israeli blockade now isolates it from the rest of the world.

\section{$>$ Hamas}

Founded in 1987, Hamas is a Palestinian Islamist ideological and insurgent organization that has conducted a campaign of terror towards Israel, primarily via bomb attacks and missile strikes. Its goal is to overthrow Israel and replace it with a Palestinian state, according to the organization. Also, on its own, without the assistance of the Palestinian Leadership, it governs the Gaza Strip.

\section{$>$ Fatah}

Fatah was founded in 1959 by members of the Palestinian diaspora, mainly professionals working in the Persian Gulf States who had been educated in Cairo or Beirut and had previously been refugees in Gaza to fight for Palestinian rights. Fatah promoted a Palestinian nationalist ideology based on the idea that Palestinian Arabs might free themselves via their actions. After the 1967 Six-Day War, Fatah became the most powerful political movement in Palestine. In 1967, Fatah became a member of the Palestinian Liberation Organization (PLO) and was given 33 of 105 seats on the PLO executive committee. Yasser Arafat of Fatah was elected Chairman of the Palestinian Liberation Organization (PLO) in 1969.

\section{$>$ Palestine Liberation Organization (PLO)}

The Palestine Liberation Organization is the Palestinian people's national representation. It is in charge of the Palestinian National Authority (PA), a self-contained administration implecated administering Palestinian land until a settlement along Israel is extended. Fatah, a secular nationalist political party that has dominated Palestinian politics for decades, controls the PLO and the PA. The Palestinian Liberation Organization (PLO) governs the West Bank, while Hamas governs Gaza. It also participates in peace negotiations on behalf of Palestinians, although a problematic relationship with Hamas has hindered its capacity to implement accords.

\section{$>$ Zionism}

Zionism is Israel's national ethos. Zionists believe that Jews deserve their state in Israel, their ancestral homeland. Jews usually trace their origins to the 950 BC kingdoms of David and Solomon. This century's Zionism sprang out of a long-held Jewish yearning to "return to Zion." Theodor Herzl, a secular Austrian-Jewish writer, was the first to internationalize Jewish nationalism in 1896.

\section{$>$ West Bank}

The West Bank is a strip of land to the east of Israel. It is home to around three million Palestinians and would serve as the foundation of any future Palestinian state. Israel captured it in 1967 and allowed Jewish settlers to reside there, even though Palestinians and most of the international community see it as illegally stolen Palestinian land.

\section{The Palestinian Intifadas}

Two Palestinian upheavals towards Israel occurred during the Intifadas, the first in the late 1980s and the second in the early 2005s. The Intifadas had a profound impact on Israel's ties with Palestine. During the first Intifada, Palestinian tactics included suicide attackers, missile launchers, and grenade fire, which Israel responded to with much more lethal force. The second Intifada and the surge of airstrikes from Gaza after Hamas's control had a profound impact on Israeli views about the conflict.

\section{Jerusalem}

Jerusalem is a city that sits on both sides of the Israeli-West Bank boundary. Both Israel and Palestine seek to make it their capital since it is home to some of the holiest sites in both Judaism and Islam. One of the significant problems separating Israelis and Palestinians is how to divide the city equitably. On Israel's side, President Donald Trump chimed in during Israel's first 20 years of existence, Jerusalem was shattered. Jordan was in charge of the Temple Mount, Western Wall, Al-Aqsa Mosque, and Dome of the Rock. Israel grabed jurisdiction of East Jerusalem during the 1967 war; However, the US position allows for negotiations about which parts of Jerusalem would be permanently Israeli and handed to Palestine if a peace agreement is achieved.

\section{Findings AND ANALYSIS}


The Israeli-Palestinian conflict is a disaster in the Middle East. Every Middle Eastern country has been engaged in this war. The following are the reasons behind this dispute, as determined through analysis:

\section{a. The Religious Issue Between Islam and Zionism}

Multiple doctrinal components distinctive to Islam and Judaism necessitate the inclusion of faith as the dominant reason in the controversy, most notably the true meaning of sacred city and the eschatological stories including both religions, which are detrimental to any possibility of a peaceful settlement between both the two parties; and Religious fanaticism In Israel, Zionists rapidly still perceive themselves as protectors and descriptors of the Jewish nation's principles. They are vehement in their opposition to any compromises with the Palestinians. On the other side, Islamist organizations in Palestine and the Islamic world argue for the theological imperative of freeing the "holy" lands and places and teaching violence and hate against Israel and the Jewish people.

\section{b. Israel and Palestine Territories}

The conflict between Palestinians and Israelis revolves around land. Land serves as patriotic and ideological symbols, further complicating the conflict's underlying dynamics. The conflict amid the conflict among Palestinians and Israelis for land resulted in the clashes of 1948 and 1967 and numerous insurgencies (Intifadas). In 1991, at the Madrid Conference, it was agreed that, the phrase "land for peace" took place to accepted in the act of leading concept being future talks to settle the conflict. This formula emphasizes the significance of land concerns in resolving the dispute. The Palestinian entity has been fractured due to Israeli occupation and colonization practices, with restricted entrance to this property, and Legal ownership of environmental assets is required. Environmental assets must be legally protected and maintained. As a consequence, Palestinians have become so financially dependent on Israel that their prolonged survival is endangered.

\section{c. Water Scarcity}

Palestinian water rights include the West Bank and the Gaza aquifers and a riparian portion of the Jordan River. Israel has denied Palestinians access to water. Water from West Bank aquifers is currently taken over by Israel, accounting for 85 percent of Palestinian water and 25 percent of Israel's water needs. In the West Bank and the Gaza Strip, about 286 MCM of water is available to satisfy the needs of three million Palestinians. The Palestinian entitlement to water in the West Bank and Gaza Strip is anticipated to boost the demand of $900 \mathrm{MCM}$. Less than six million Israelis utilized 1,959 MCM in 1998. (ARIJ, 2000). Water is used extensively by Jewish colonists in the West Bank and Gaza Strip. Annually, 6900 Gaza colonists and 350 thousand West Bank colonists (including East Jerusalem) consume 10 and 65 MCM, respectively (ARIJ, 2000). The Jewish colonists have constant access to Palestinian water resources, whereas the Palestinians have only sporadic access, particularly in the summer. It is built on water resources. For example, in Bethlehem district, $29 \%$ of Israeli urban growth is in water vulnerable areas. Moreover, Israel continues to obstruct the attempts of the Palestinian Water Authority (PWA) to link $25 \%$ of the Palestinian population to home water networks.

\section{d. Food Crisis}

Since the beginning of the Invasion in 1967, Israel has stolen hundreds of thousands of designs that carried Palestinian land to build improper colonies, warlord highways, and the Segregation Wall in the West Bank, among other things. The 519 checkpoints, barricade, and other restrictions across the West Bank make farming difficult. Israeli soldiers and settlers often destroy and vandalize farmers' land and crops in the West Bank. The "buffer zone" that borders Israel has cost Gaza farmers $25 \%$ of their most productive agricultural land. Anglers may only fish three nautical miles offshore, just $15 \%$ of Gaza's lawful territorial seas guaranteed by the Oslo Accords. As a result of the Israeli siege of Gaza, 80 percent of Gaza's population is reliant on international emergency food assistance. Palestinians cannot achieve agricultural sovereignty due to Israeli land expropriation and devastation, trade restrictions, environmental problems, and a rising global food crisis.

\section{e. Natural Resources}

The total forest area within legally designated areas has dropped from 30,074 to 23,159 hectares between 1971 to 1999. (Ministry of Agriculture of the PNA). Gaza lost 95\% of its woods, accounting 
for almost half of the loss (to 200 hectares in 1999, down from 4,200 hectares in 1971.). Approximately $80 \%$ of the authorized woodland is destroyed as a result of Occupied territories owing to army bases (2\%), settlements (78\%) and bypass roads (below 1 percent ). Palestinians have access to just 35\% (8010, hectares) of the designated forest area (Arij, 2000).

Moreover, Israel has devastated huge Palestinian agricultural lands. So, among September 2000 and March 2001, Israeli troops "shaved" 298 hectares of soil in Gaza, removing all living things off the surface. The Israeli soldiers, settlers, or a combination of the pair uproot trees, an execution that has escalated throughout the burning Intifada. Seventy-five percent of Israeli colony urban development on cultivated land is expected to be on vineyards.

\section{f. The Implications of the Political Dynamics in GCC}

Israel has built a strong relationship with the Gulf Cooperation Council (GCC) nations, effectively linking their security interests and concerns with Iran as a regional adversary. On the other hand, Palestinians see such developments as detrimental to their political cause since Israel remained the occupying authority in the Palestinian lands. Israel seems to be using the Palestinian suffering as leverage to improve its ties with Arab monarchs since the GCC nations' policies toward Israel and Palestine overlapped.

\section{RECOMMENDATIONS}

Some recommendations are made to bring about a solution to the Israeli-Palestinian conflict. These are the things to look out for:

\section{a. Palestinian Refugees}

The termination of the Palestinian refugee problem, the United Nations Relief and Works Agency for Palestinian Refugees in the Near East (UNRWA) should be decommissioned, and Arab governments should help Palestinian refugees to gain the basic facilities of a citizen. The United Nations' involvement in the Palestinian refugee crisis has been critical. The United Nations Relief and Works Agency for Palestine Refugees in the Near East (UNRWA) was established by UNGA Resolution 302 on December 8, 1949, after the Arab-Israeli conflict. Its goal was to provide "direct assistance and employment initiatives for Palestine refugees." The reluctance of Arab nations to integrate Palestinians is another significant reason that has resulted in the Palestinians being refugees for almost 70 years. The Arab nations surrounding Israel, except Jordan, have refused to give Palestinians citizenship. Arab countries have adopted anti-Palestinian laws that limit Palestinian refugees' property ownership rights, their ability to join certain professions, travel, and access to health care and education. "If the refugees return, there won't have a two-state solution; there will have a Palestine next to a Palestine, rather than a Palestine next to Israel," Omar Barghouti, the originator of the Boycott, Divestment, and Sanctions movement, said. The Palestinian Liberation Organization (PLO), whose original charter advocated for Israel's destruction, has refused to give up the right of return. "The refugee problem is the winning card that signifies the end of the Israeli state," said Sakher Habash, a prominent Fatah member and adviser to Yasser Arafat, in 1998.

\section{b. Israeli Settlements}

Israel imposes a dominant rule between Jordan and the Mediterranean, including the West Bank. Although not officially annexed, Israel's enormous resources to build settlements and establish infrastructure to support them demonstrates de facto status. The Israeli Information Center reports that approximately 2 million decares (nearly 800 square miles) of Palestinian land had been confiscated. On the other hand, highways link the West Bank settlements to Israel's sovereign territory west of the Bay Bridge. The United Nations Relief and Works Agency for Palestinian Refugees in the most significant Jewish settlements near the Israeli border would officially become Israeli territory. In return, Israel would hand up an equivalent portion of its present region to become part of a Palestinian state. Furthermore, settlements deep in the West Bank, distant from Israel, would be dismantled. It would be a tough political decision for an Israeli prime minister, but it would equally be difficult for a Palestinian leader to accept a peace agreement without eliminating settlements. 


\section{c. The Two-State Solution}

There is a two-state solution envisions two states, a single one of Israel and Palestine, coexisting peacefully. Israel already exists as a sovereign state, and its boundaries would essentially return to those in place from 1949 to 1967. Palestine will be formed in the Gaza Strip and a connected part of the West Bank that would encompass 95 percent or over of the territory of the West Bank, according to UN Resolution 242. In Jerusalem, the headquarters of both countries will be located, with Israel's legitimate office located in West Jerusalem and Palestine's governmental center based in East Jerusalem. Still, a precise splitting would be complex due to the Israeli settlements (neighborhoods) surrounding East Jerusalem's heart. The Old City of Jerusalem, as well as perhaps other nearby sacred sites will be:

1. Shared.

2. Under the auspices of an international commission.

3. Divided in some manner between the two countries.

The Palestinians rejected Trump's advisor and son-in-law Jared Kushner proposed two-state solution because it envisaged a Palestinian state with limited authority and Israel retaining security over it.

\section{d. One State Solution}

A one-state solution implies that pre-1967, Israel, the Gaza Strip, and the West Bank would become a single nation. This potentate state will be called "the Holy Land" as a placeholder. Individual rights would be equal for everyone living among the Jordan River and the Mediterranean Sea, irrespective of racial or religious ties. They would be able to live wherever they chose in the Arab World and participate in state elections. The headquarters might be Jerusalem, and the government will be made up of Jews and Palestinians. Since, a single state may be based only on equitable personal liberty, or it could be a secular democracy in which both groups (Jews and Palestinians) have communal rights.

\section{CONCLUSiON}

In May 2021, the Israeli-Palestinian war resurfaced, with many wondering when it will end. The human toll is high. Millions of Palestinians and Israelis were anxious. Hundreds died, hundreds were injured, and tens of thousands were displaced. It is hardly surprising that almost $90 \%$ of the dead and displaced were Palestinians. A diplomatic solution might theoretically end the war. To bring the Conflict to a close, the following questions must be answered: How should Palestinian refugees be treated?; What should be done about Israeli settlements within Gaza and the West Bank?; Is it possible to creat a State of Palestine next to Israel?. If the world's leader can provide answers to these issues, the problem may be resolved and mediated. Otherwise, that century-old dispute will be resolved over a longer period of time.

\section{REFERENCES}

[1] Bader Araj \& Robert J. Brym, "Intifada, Palestinian-Israeli history," Britannica, 2006. https://www. britannica.com/contributor/Bader-Araj/9398169, access date 12 July 2021.

[2] Green \& Charles, Examples of Four Types of Conflict. Human Resources, 2012.

[3] "Israel-Palestine Conflict," Council for Arab-British Understanding, https://www.caabu.org/, access date 01 August 2021.

[4] John Lewis Gillin \& John Philip Gillin, Cultural Sociology: A Revision of an Introduction to Sociology, Macmillan Company, 1948.

[5] "Palestine" History .com Editors,2021. access date 12 August 2021. https://www.history.com/topics/ middle-east/palestine.

[6] The Applied Research Institute Jerusalem (ARIJ), 2000.

[7] Yaacov Bar Siman Tov, (editor), Barriers to Peace in the Israel-Palestine Conflict, The Jerusalem Institute for Israel Studies, Study no. 406, 2010. 


\section{AUTHOR'S BIOGRAPHY}

Dr. Fahmida Aktar, is an Associate Professor at Shahjalal University of Science and Technology in Sylhet, Bangladesh. She received her Ph.D. in Bangladeshi Foreign Policy and Bangladesh-India Relations. She is very interested in International Politics and International Relations. She has written many research articles on South Asian Trade Integration, India's River Linking Project, Blue Economy and Ocean Governance, the Rohingya Refugee Crisis, and Bangladesh-India Connectivity in prestigious Journals of Humanities, Social Science, and Education.

Citation: Dr Fahmida Aktar. "Israel-Palestine Conflict: How Far the Solution is?" International Journal of Humanities Social Sciences and Education (IJHSSE), vol 8, no. 9, 2021, pp. 19-27. doi: https://doi.org/10.20431/2349-0381.0809003.

Copyright: () 2021 Authors. This is an open-access article distributed under the terms of the Creative Commons Attribution License, which permits unrestricted use, distribution, and reproduction in any medium, provided the original author and source are credited. 